\title{
Undersøgelserne ved Trøjborg i 1957
}

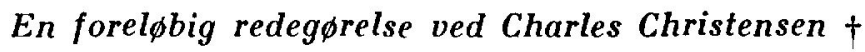

Trøjborg er Sønderjyllands st $\varnothing$ rste ruin og virker meget malerisk, som man ser den mellem grønne træer og frodige enge. Der har været større vandarealer uden om de mange jordvolde, som i gamle dage gav - mente man - stedet stor betydning som forsvarsværk; der fandtes tre vandfyldte grave med tilløb fra en å, og man havde opstillet palisader ved kanterne. Braunius' stik fra ca. 1585 viser de oprindelige ongivelser, men noget fortegnet.

Peter Rantzaus hovedbygning fra 0.1580 havde hjørnetårne indvendig $i$ hvert af gårdens fire hjørner. Det viste sig ved udgravningen i 1957, at der var to større og to mindre tårne; om der har været trapper i dem alle, er dog et spørgsmål. Der er ikke fundet stykker af sandsten, så trinene har været af træ; det nordvestre hjørnetårn har haft en portal af teglsten ind mod gården. Inden unders $\varnothing$ gelsen i 1957 var der fremsat den formodning, at

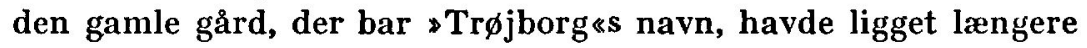
mod $\varnothing$ st end den nuværende. Men der påvistes ved udgravning på voldstedet rester af $3-4$ gårde ældre end den kendte ruin af Peter Rantzau's bygning. Det siges, at en af broerne brød sammen, da man kørte de nedbrudte teglsten bort; kun sydmuren står nu delvis tilbage $i$ den oprindelige højde. Det må have været mænd med store midler, der har bygget Trøjborg. Dronning Margrethe skal have fået den efter hertug Valdemar; hun ejede også Brundlund ved Åbenrå. Senere kom Trøjborg under Ribe-bisper, som skal have bygget på borgen i 1442 .

Fra senere tid må omtales Daniel Rantzau, der 1566-68 stod som ejer. Men det blev hans broder Peter, der opf $\phi r t e$ den store røde gård med de mange sandstensdekorationer, som vi under udgravningen prøvede at samle sammen, og han indsatte også den store tavle med indskrifterne, der sad over porten.

Det lykkedes at få bjerget en del af de tilhuggede sandsten, 
der lå $\mathrm{i}$ vandgravene og ved den ny gård; mange af dem har siddet som volutsten $i$ gavlene og som våbensten med L $\phi$ ven *, der nu findes på museet i T $\emptyset$ nder. Iblandt fandtes også rester af smukke sandstenskaminer med mange fantasirige former. Disse sandstensfragmenter blev opmålt for $\mathrm{Ny}$ Carlsbergfondets bevilling, og tegningerne findes nu i Nationalmuseet.

Ruinerne var helt overgroet med træer og buske, hvis rødder havde sprængt de forvitrende mure. Sydmuren har for nogle år siden fået en st $\varnothing$ rre udbedring, og Nationalmuseet har planlagt at give hele ruinen en omfattende istandsættelse.

Det nord-østre tårn viser mange revner, da det dels har stået på rester af muren fra 2 . byggeperiode og dels på løs jord eller opfyld.

Da man nedrev pygning $\mathrm{nr}$. II, lod man en del af dens vestmur blive stående og benyttede de vestligste skifter ved opførelsen af en ca. $2 \mathrm{~m}$ tyk mur, der dog spidser noget til opefter;-man havde hermed påbegyndt et Trøjborg nr. III; denne mur fra Trøjborg III er måske opf $\varnothing \mathbf{r t}$ i flere omgange, men lader i $\emptyset$ vrigt meget tilbage at $\emptyset$ nske både med hensyn til materiale og opf $\varnothing$ relsesmåde. Stenene fra mur III går højt op til slotsgården; sidste bro støder op til gård III.

En ældre bro har rester ca. 1/2 m herunder, og murstenene fra gård III er lyserøde og meget skøre og sandede; man forstår derfor godt, at da man byggede gård nr. IV, (Peter Rantzaus hus), benyttede man kun meget få af de gamle, lyse og skøre mursten. De nye sten, man benyttede til Trøjborg nr. IV, var gode nok. Der er udsparet kanaler i murværket antagelig som afløb fra hemmeligheder (latriner) i nordvest- og østmurene. Disse kanaler blev renset op i 1957, og mange sk $\phi$ rnede lerkar og andet kom derved frem og blev afhentet af Nationalmuseets medarbejdere. Der fandtes også her rester af sandstensdekorationer og profiler, som forel $\varnothing$ big opbevares af Nationalmuseet. Foruden nedfaldsskakterne fra hemmelighederne fandtes murkanaler til ophejsning af vand, og man ser $i$ murværket slidmærkerne fra tovene. Vandkanalerne lå langt fra hemmelighederne Der var også stykker af kridtpiber og på skafterne stod »Gauda glasmalerier i Holland. 


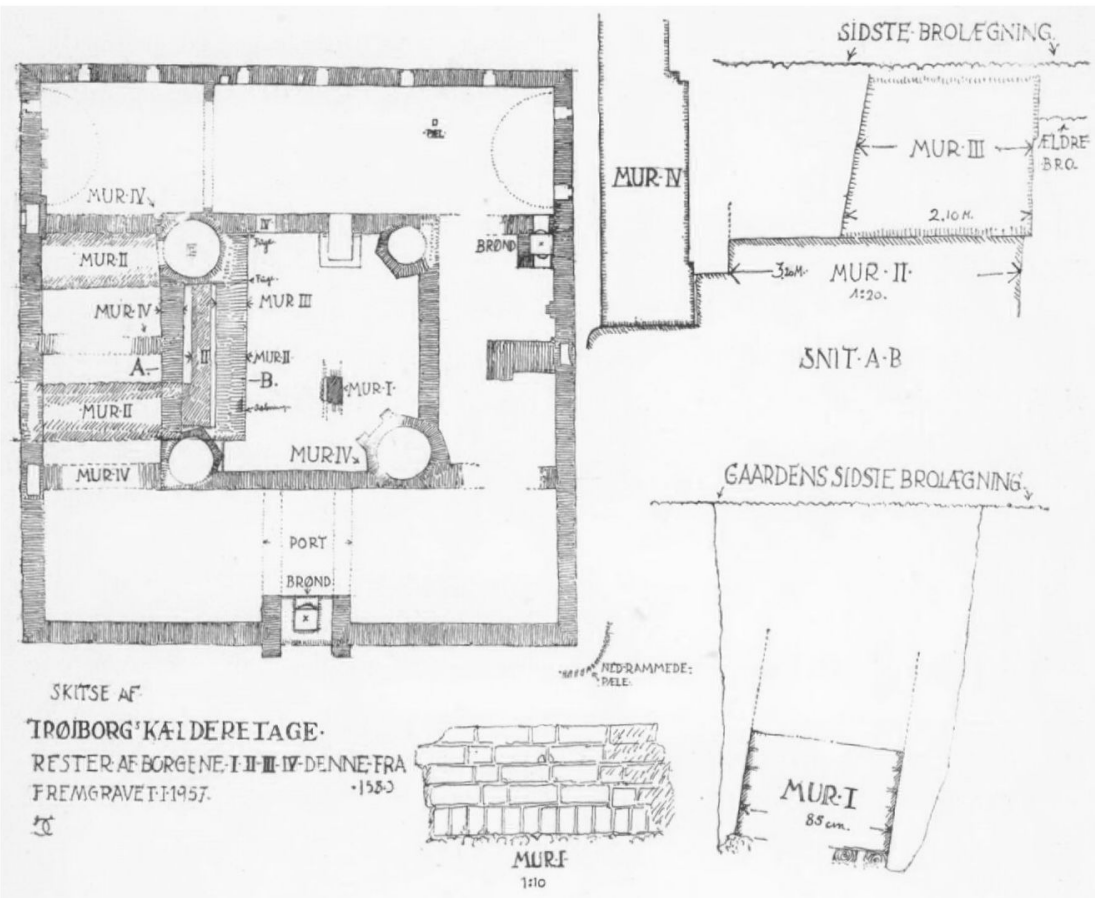

Der fremkom et mærkeligt lodret tømmerstykke, der ikke så ud til at have forbindelse med Peter Rantzaus gård. Det var nedrammet $i$ ret teglstensfrit jordlag under sydfløjens jordgulv.

At der allerede $i$ den ældre middelalder har ligget murværk af teglsten på stedet, fandt man beviser for på vestre del af gårdspladsen. Det middelaldermurværk, der her blev påvist, var en $85 \mathrm{~cm}$ tyk murklods, der lå ca. 2 meter nede under gårdspladsens nuværende niveau; den bestod af røde teglsten $i$ regelmæssig munkeskifte. Det viste sig, at den stod skævt, ude af lod, og grunden hertil var, at murklodsen var funderet på to forskellige måder; den ene side stod på et fundament af små faste teglstensstykker, den anden kant var bygget på træplanker, der delvis var rådnet bort, derfor havde murstykket fået slagside. Hele vejen rundt - også andre steder - har man benyttet træbjælker at fundere på. En anden bygning, noget yngre end Trøjborg I, traf vi i 
anlæggets $\emptyset$ stlige del. Der var her tale om $3 \mathrm{~m}$ tykt murvark, men der stod kun ringe dele af de tykke ydermure - flere steder kun et enkelt teglstensskifte. Det har været et rum på ca. 5 m $\times$ $5 \mathrm{~m}$ mellem ydermurene.

Da man nedrev gården nr. II, lod man en del af vestmuren blive stående fra gård nr. II. Bygning nr. I var da forlængst forsvundet.

Af gård nr. IV eksisterer et ret hæderligt maleri fra 1830; og dele af de sandstenss $\varnothing j$ ler, som ses at have flankeret porten, traf vi forskellige steder i 1957. De viste doriske former, men der mangler nu rester af de trekvartsøjler, der har indfattet selve portåbningen.

Den store tavle med indskriften, der fortæller om gårdens tilblivelse, er ret velbevaret. Det samme gælder våbentavlerne på siderne. I god stand er også den øvre trekant med de to liggende kvindefigurer: En mager kvinde med et timeglas, en svulmende med et dødningehoved som st $\emptyset$ tte for den ene arm.

To sådanne symbolske kvindeskikkelser findes endnu på Kronborg, men velpåklædte; symbolerne timeglas og d $\varnothing$ dningehoved er de fælles om; Kronborg-figurerne er vel de aldste, fra ca. $1574-75$.

På Uranienborg var der ligeledes liggende småfigurer, dog mandlige, men de har vel symboliseret kemien og astronomien. Vi kender navnet på den billedhugger, der har udf $\phi r t$ de to figurer på Kronborg; det var Gert v. Gronningen, som o. 1575-76 virkede i Jylland. Fra hans værksted er udgået mange arbejder, gravsten m. m., mange af dem er udført med sande kunstnerhænder.

En sammenstilling mellem skulpturerne fra Trøjborg og fra Uranienborg (1576-80) er ikke tidligere foretaget, ligesom man ikke tidligere har været særlig opmærksom på det nære venskab mellem familierne Brahe og Rantzau. Trøjborgs våbenløver, nu i Tønder museum, er nogle tamme eksemplarer af racen, nej, vil man se løver, der viser os naturens vildskab, skal det være på Kronborg eller Vallф (1581).

Der er også et andet træk, der er særligt for Trøjborg, det er den store bredde på de svungne, buede gavlafdækninger. Ingen 
andre steder i landet har sandstensafdækninger så store ydre forflader. Kun på Uranienborg havde man tilsvarende størrelser på disse i $\emptyset$ jnefaldende steder. På Trøjborg er de opdelt i fyldinger. Fra Uranienborg har man ingen sikre holdepunkter om dekorationerne på afdækningens forflader.

Den idé med løven, der har forpoterne på våbenskjolde, havde man vel fra Kronborgs store tårn, - det ses på gamle stik ældre end 1658. På Kronborg er løverne vel fra 1580'erne og forsvandt for ca. 300 år siden ved tårnets udbedring efter krigen med svenskerne.

Formålet med den stedfundne opmåling af Trøjborg slotsruin var at tilvejebringe et n $\varnothing$ jagtigt materiale til bed $\phi$ mmelse af Peter Rantzaus kultiverede hus og et sikkert grundlag for en restaurering af ruinen. Hertil kom så, at udgravningerne som en ekstra gevinst gav oplysning om, at der på samme sted har ligget tre, måske fire, ældre borge. En mere detaljeret redegørelse for undersøgelsens resultater kan forventes udgivet af Nationalmuseet. 